\title{
Spring Habitat Requirements of Captive-Reared Attwater's Prairie Chicken
}

\author{
Mitchell A. Lockwood, ${ }^{1}$ Michael E. Morrow, ${ }^{2}$ \\ Nova J. Silvy, ${ }^{3}$ and Fred E. Smeins ${ }^{4}$

\begin{abstract}
Authors are ${ }^{1}$ Wildlife Biologist, Texas Parks and Wildlife Department, 328 Highway 27 West, Ingram, TX 78025;
${ }^{2}$ Wildlife Biologist, Attwater Prairie Chicken National Wildlife Refuge, PO Box 519, Eagle Lake, TX 77434;

${ }^{4}$ Professor, Department of Rangeland Ecology and Management, Texas A M University, College Station, TX 77843.
\end{abstract} \\ ${ }^{3}$ Regents Professor, Department of Wildlife and Fisheries Sciences, Texas AひM University, College Station, TX 77843; and
}

\begin{abstract}
During the summer of 1996, 50 radio-tagged, pen-reared Attwater's prairie chickens (Tympanuchus cupido attwateri) were released on Attwater Prairie Chicken National Wildlife Refuge in a restoration effort to supplement a wild population. We evaluated fine-scale habitat use of pen-reared Attwater's prairie chickens during the 1997 nesting season based on 4 variables: obstruction of vision, plant height, litter depth, and percentage of bare ground. Low obstruction of vision (mean $=1.5 \mathrm{dm}$ ), plant height $($ mean $=67.3 \mathrm{~cm})$, and litter depth $($ mean $=2.7 \mathrm{~cm})$ characterized preferred habitats. Bare ground averaged $16.5 \%$ at Attwater's prairie chicken locations compared with $8.2 \%$ at random locations. Use locations differed from random locations with respect to visual obstruction $(P<0.001)$, plant height $(P<0.001)$, litter depth $(P<0.001)$, and bare ground $(P=0.007)$. Potential release sites should be managed using prescribed burning and controlled grazing to produce vegetative structure with an obstruction of vision $\leq 1.5 \mathrm{dm}$, plant height $\leq 67.3 \mathrm{~cm}$, litter depth $\leq 2.7 \mathrm{~cm}$, and percentage of bare ground $\geq 16.5 \%$ ), the preferred habitat of pen-reared Attwater's prairie chickens.
\end{abstract}

\section{Resumen}

Durante el verano de 1996, 50 pollos de “Attwater's prairie”(Tympanuchus cupido attwateri), criados en corral y con equipo de radiotelemetría, fueron liberados en el Refugio Nacional de Fauna Silvestre Attwater Prairie Chicken como un esfuerzo para restaurar y reforzar la población natural de esta especie. Durante la época de anidamiento de 1997 evaluamos a nivel de escala fina el uso del hábitat por los pollos liberados, la evaluación se basó en 4 variables: obstrucción de la visión, altura de planta, profundidad del mantillo y porcentaje de suelo descubierto. La Baja obstrucción de visión (promedio = $1.5 \mathrm{dm}$ ), la altura de planta (promedio $=67.3 \mathrm{~cm}$ ) y la profundidad del mantillo (promedio $=2.7 \mathrm{~cm}$ ) caracterizaron los hábitats preferidos. El suelo descubierto promedio el $16.5 \%$ en las localidades de los pollos de "Attwater's prairie" en comparación con $8.2 \%$ en sitios elegidos aleatoriamente. Los sitios utilizados difirieron de los sitios aleatorios con respecto a la obstrucción visual $(P<0.001)$, altura de planta $(P<0.001)$, profundidad del mantillo $(P<0.001)$ y suelo descubierto $(P=0.007)$. Los sitios potenciales de liberación deben ser manejados utilizando el fuego prescrito y el apacentamiento controlado para producir una estructura vegetativa con una obstrucción visual $\leq 1.5 \mathrm{dm}$, una altura de planta $\leq 67.3 \mathrm{~cm}$, una profundidad de mantillo $\leq 2.7 \mathrm{~cm}$ y un porcentaje de suelo descubierto $\geq 16.5 \%$, características del hábitat preferido por lo pollos de “Attwater's prairie" criados en corral.

Key Words: Tympanuchus cupido attwateri, endangered species, tallgrass prairie, supplemental releases

\section{INTRODUCTION}

Attwater's prairie chicken (Tympanuchus cupido attwateri) is currently the most endangered bird in the United States. Once estimated to number nearly 1 million individuals (Lehmann 1941), there were only 42 wild Attwater's prairie chickens estimated to exist in 1996 (USFWS unpublished data, 1996).

Research was funded by US Fish and Wildlife Service.

At the time of the research, Mitchell A. Lockwood was research assistant, Department of Wildlife and Fisheries Sciences, Texas A\&M University, College Station, TX 77843.

Correspondence: Mitchell A. Lockwood, Texas Parks and Wildlife Dept, 328 Hwy 27 West, Ingram TX 78025. Email: Mitch.Lockwood@tpwd.state.tx.us

Manuscript received 30 May 2003; manuscript accepted 23 October 2004.
Populations began declining in the early 20th century as a result of excessive harvest and habitat loss. Lehmann (1941) estimated Attwater's prairie chickens inhabited approximately 2.4 million ha of coastal prairie from southwestern Louisiana to the Nueces River on the Texas coast during the early 1900s. However, by 1937, the area of suitable habitat occupied by Attwater's prairie chickens was reduced to approximately 185000 ha ( $92 \%$ loss) and numbers had declined to 8700 birds (Lehmann 1941). By 1992, approximately 80000 ha (97\% loss) of suitable habitat remained (USFWS 1993; Peterson 1994).

By 1992, the population had dropped so low (432 birds) that the Attwater's Prairie Chicken Recovery Team initiated a captive-breeding program to supplement the wild population with pen-reared birds to avoid extinction. An assessment by the Captive Breeding Specialist Group of the International Union for 
Conservation of Nature indicated that without supplementation from captive populations all wild populations of Attwater's prairie chickens were predicted to be extinct by the year 2000 (Seal 1994).

Evaluating habitat use of pen-reared Attwater's prairie chickens is an integral component of the Attwater's prairie chicken restoration program. Knowledge of range sites and management practices preferred by pen-reared Attwater's prairie chickens is crucial when considering future release sites. Pen-reared Attwater's prairie chickens should use similar habitats preferred by wild birds; however, little is known about fine-scale habitat requirements of Attwater's prairie chickens.

Our objectives were to determine vegetative structure preferred by pen-reared Attwater's prairie chickens during the nesting season. Based on previous research by Morrow (1986) on wild birds at Attwater Prairie Chicken National Wildlife Refuge, we hypothesized that Attwater's prairie chickens would occupy areas with lower plant heights, lower visual obstruction, less litter depths, and more bare ground than found at random locations.

\section{STUDY AREA}

\section{Site Description}

This study was conducted on the 3248 -ha Attwater Prairie Chicken National Wildlife Refuge located in eastern Colorado County, Texas (lat $29^{\circ} 40^{\prime} \mathrm{N}$, long $96^{\circ} 16^{\prime} \mathrm{W}$ ), located on the border of the Gulf Prairies and Marshes Ecoregion and the Post Oak Savannah Ecoregion (Gould 1975). The San Bernard River, a boundary between Austin and Colorado counties, bordered Attwater Prairie Chicken National Wildlife Refuge to the east. The refuge, along with an adjoining 4 450-ha tract to the east, was an island of native, coastal prairie surrounded by agricultural fields, primarily rice. Other adjoining properties, not in agricultural production, were heavily infested with woody vegetation, primarily McCartney rose (Rosa bracteata J.C. Wendl.), baccharis (Baccharis halimifolia Linnaeus), wax myrtle (Myrica inodora Bartr.), and Chinese tallow (Sapium sebiferum [L] Roxb.).

Dominant range sites included deep sand $(36.5 \%)$, loamy prairie $(34 \%)$, and claypan prairie $(23.9 \%)$. Claypan range sites with $1 \%-3 \%$ slopes resulted in poor drainage. Prairie grasslands comprised approximately $71 \%$ of Attwater Prairie Chicken National Wildlife Refuge (Morrow et al. 1996), with climax species including little bluestem (Schizachyrium scoparium [Michx.] Nash), big bluestem (Andropogon gerardii Vitman), Indiangrass (Sorghastrum nutans [L.] Nash), and switchgrass (Panicum virgatum L.). Common forbs included gayfeather (Liatris sp. Gaertn. ex Schreb.), lance-leaf Indian plantain (Cacalia lanceolata Nutt.), sunflower (Helianthus sp. L.), sensitive brier (Shrankia sp. Willd.), and cone flower (Rudbeckia sp. L.). Riparian zones were dominated by live oak (Quercus virginianai P. Mill.), black willow (Salix nigrai Marsh.), sycamore (Platanus occidentalis L.), yaupon (Ilex vomitoria Ait.), and McCartney rose. Morrow et al. (1996) described range condition of refuge grasslands as varying from poor on formerly cultivated areas to good on unbroken prairie.

\section{Habitat Management}

Management practices, including prescribed burning, controlled grazing, herbicide applications, native grass seeding, and mowing, were implemented in 1983 to maintain a clumped, midgrass community as recommended by Horkel (1979). Area burned each year (December-February) ranged from 800 to 1200 ha. The cattle-grazing regime consisted of a 4-pasture, 3herd rotation with approximately $5.5 \mathrm{ha} \cdot$ animal unit $(\mathrm{AU}) \cdot \mathrm{y}$. Tebuthiuron (N-[5-(1,1-dimethylethyl)-1,3,4-thiadiazol-2-yl]- $N$, $\mathrm{N}^{\prime}$-dimethylurea) and a mixture of Picloram (K salt [4-amino3,5,6-trichloropicolinic acid]) and 2,4-DB (4-[2,4-dichlorophenoxy] butyric acid) were used to control brush encroachment. Native grasses, baled on the refuge, were transported to former rice fields and provided a seed source. Approximately 10 to 25 ha of food plots located in the center of the refuge were planted each fall with soybeans and sunflowers.

\section{METHODS}

From 19 July 1996 through 4 September 1996, 50 pen-reared Attwater's prairie chickens were released on Attwater Prairie Chicken National Wildlife Refuge. All released, pen-reared Attwater's prairie chickens were equipped with mortalitysensitive radio transmitters (Lockwood 1998). Birds were monitored daily, using a 5-element yagi antenna mounted through a truck roof. Attwater's prairie chicken locations were determined by triangulation as described by White and Garrott (1990) and were plotted on a cover map to determine habitat use.

Stocking rate (AUM $\cdot$ ha) for each pasture was recorded by refuge personnel (USFWS, unpublished data, 1997). A Pearson Product-Moment Correlation Coefficient (Ott 1993) was used to determine if there was a relationship between the percentage of Attwater's prairie chicken radio locations within each pasture and the stocking rate.

Precipitation for 1996 and 1997 (recorded at the Eagle Lake Research Station, Eagle Lake, Texas) was compared with the long-term average precipitation for the area. A modified Palmer Drought Severity Index was generated for the division of Texas that included our study area to determine the severity of wet or dry periods. The modified Palmer Drought Severity Index was based on the principles of a balance between moisture supply and demand.

To determine spring habitat requirements of pen-reared Attwater's prairie chickens, 52 vegetative samples $(26$ random Attwater's prairie chicken locations and 26 random locations) were taken from 12 May 1997 to 6 June 1997 (nesting season). Each sample consisted of a $0.1-\mathrm{m}^{2}$ quadrat centered on an Attwater's prairie chicken radio location or a random location and 8 quadrats in each of 8 cardinal directions $25 \mathrm{~m}$ from the center quadrat. Plant characteristics (obstruction of vision, plant height, litter depth, and percentage of bare ground) were measured within each of the 9 quadrats for each sample. Plant height and visual obstruction were measured at a distance of $4 \mathrm{~m}$ from each of the 9 quadrats in the 4 cardinal directions using a range pole as described by Robel et al. (1970). Therefore, each sample consisted of 36 measurements of visual obstruction and plant height and 9 measurements of litter depth and percentage of bare ground. A total of 936 measurements for visual obstruction and plant height and 234 measurements for litter depth and percentage of bare ground were collected for Attwater's prairie chicken locations and random locations. Structural measurements of vegetation for Attwater's prairie chicken and random locations were compared using 2-sample $t$-tests (Ott 1993). 


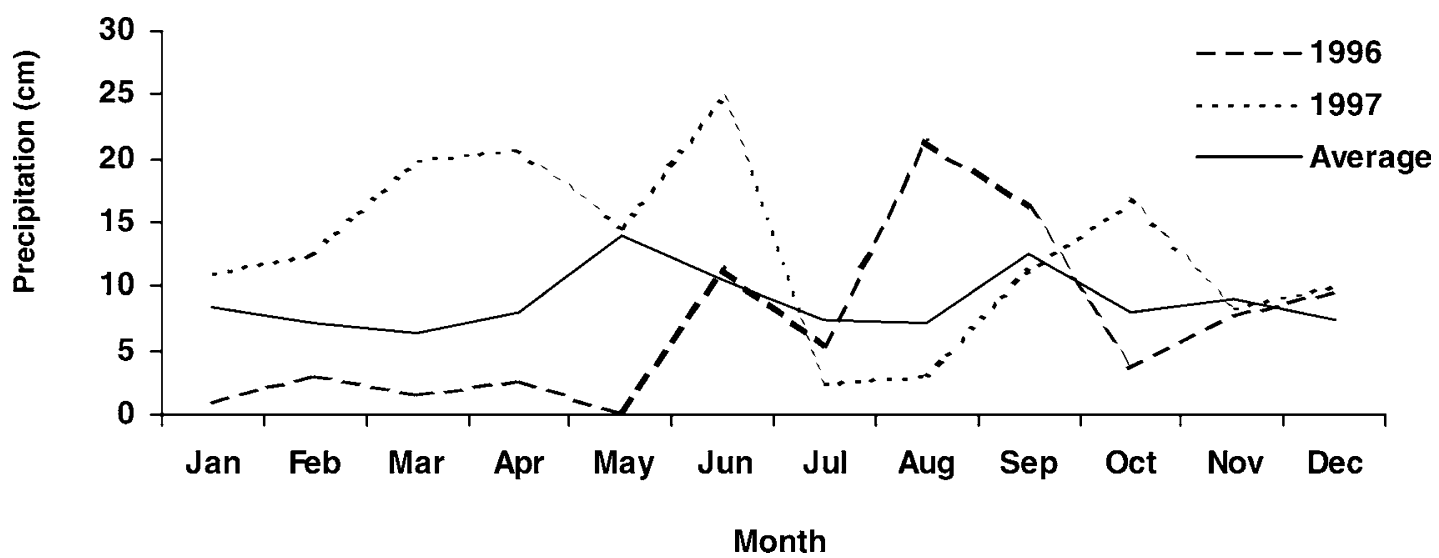

Figure 1. Diagram of average monthly precipitation for Eagle Lake, Texas compared with monthly precipitation recorded in 1996 and 1997.

\section{RESULTS}

Pen-reared Attwater's prairie chickens showed preference for loamy prairie range sites interspersed with claypan prairie range sites, and a strong preference for food plots that consisted of soybeans and fallow areas. Average stocking rates for all pastures within loamy prairie and claypan prairie range sites was 1.96 AUM $\bullet$ ha $(\mathrm{SD}=1.59)$. During spring months, only 1 pasture (Reichardt Pasture) was preferred by pen-reared Attwater's prairie chickens. The Reichardt Pasture had a greater stocking rate (4.5 AUM - ha) than all other pastures from winter 1996 through spring 1997. Bird use was positively correlated ( $r=0.893 ; P=0.041)$ with stocking rate.

Reichardt Pasture was located between the only 2 active leks (breeding grounds); thus, Attwater's prairie chicken use of Reichardt Pasture could have been a function of breedingground locations. However, Attwater's prairie chickens did not use areas closest to the center of each breeding ground to meet needs other than courtship. Mean distance (February-May) from the center of Attwater's prairie chicken (noncourting) locations was $1182 \mathrm{~m}$ from the center of Lek 1 and $591 \mathrm{~m}$ from the center of Lek 2. Nearest distances to areas avoided by Attwater's prairie chickens, surrounding 3 sides of leks, averaged $402 \mathrm{~m}$ from the center of Lek 1 and 326 m from the center of Lek 2. Attwater's prairie chickens avoided pastures that were grazed considerably less than Reichardt Pasture, although those pastures were closer to active leks than were Attwater's prairie chicken locations.

Precipitation throughout much of 1996 was below average, whereas 1997 precipitation was mainly above average (Fig. 1). The modified Palmer Drought Severity Index indicated drought conditions for all months in 1996 and wet conditions from April-December 1997 (Fig. 2).

Areas used by pen-reared Attwater's prairie chickens during the 1997 nesting season were characterized by lower visualobstruction measurements $(P<0.001)$ and plant heights $(P<0.001)$ than random areas (Table 1$)$. Mean obstruction of vision was $1.5 \mathrm{dm}$ at Attwater's prairie chicken locations and $2.1 \mathrm{dm}$ at random locations. Attwater's prairie chickens

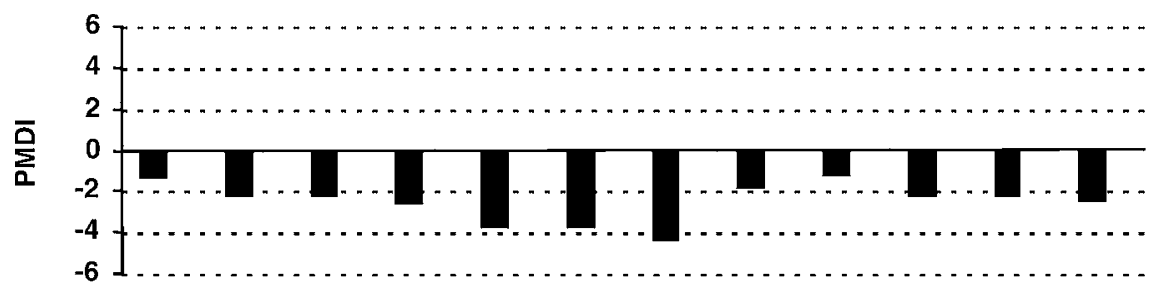

1996

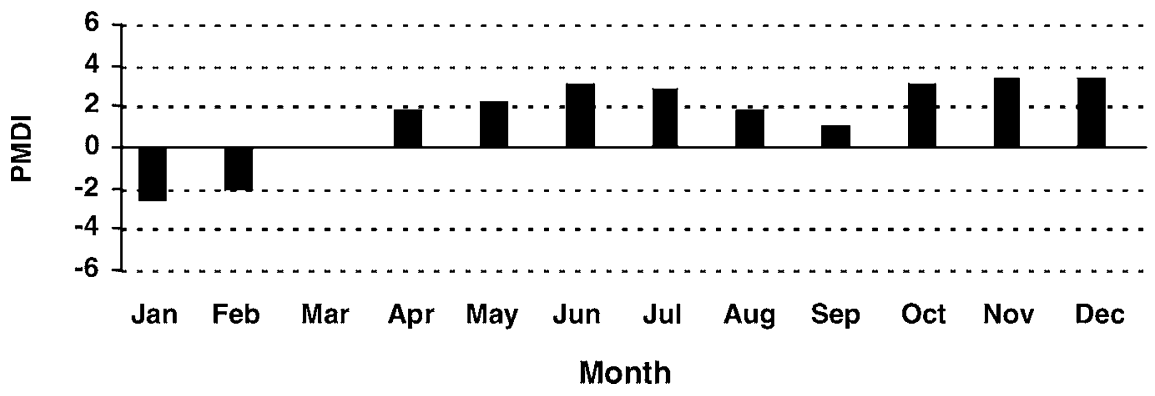

1997

Figure 2. Diagram of monthly, 1996 and 1997, modified Palmer Drought Severity Index values for the division that included our study area. Modified Palmer Drought Severity Index values 0 to -0.5 is normal; -0.5 to -1.0 indicates incipient drought; -1.0 to -2.0 , mild drought; -2.0 to -3.0 , moderate drought; -3.0 to -4.0 , severe drought; and $>-4.0$, extreme drought. Similar adjectives are attached to positive values of wet periods. 
Table 1. Mean (SD) measurements of obstruction of vision (dm), height $(\mathrm{cm})$, litter depth $(\mathrm{cm})$, and percentage of bare ground at pen-reared Attwater's prairie chicken locations and random locations. Means with standard deviation within columns followed by different letters are different $(P<0.0001)$ except for the bare ground comparison $(P=0.007)$.

\begin{tabular}{lccccr} 
Location & $n$ & $\begin{array}{c}\text { Obstruction } \\
\text { of Vision }\end{array}$ & Height & Litter Depth & Bare Ground \\
\hline Prairie Chicken & 26 & $1.5(0.5) \mathrm{A}$ & $67.3(15.0) \mathrm{A}$ & $2.1(3.4) \mathrm{A}$ & $16.5(1.4) \mathrm{A}$ \\
Random & 26 & $2.1(0.6) \mathrm{B}$ & $85.4(9.7) \mathrm{B}$ & $5.3(5.0) \mathrm{B}$ & $8.2(1.3) \mathrm{B}$ \\
\hline
\end{tabular}

used areas composed of plants that averaged $67.3 \mathrm{~cm}$ in height; whereas random areas consisted of plant heights averaging $85.4 \mathrm{~cm}$. Litter depth also was greater $(P<0.001)$ at random locations $($ mean $=5.3 \mathrm{~cm}$ ) than Attwater's prairie chicken locations $($ mean $=2.1 \mathrm{~cm})$. Percentage of bare ground was greater $(P=0.007)$ at Attwater's prairie chicken locations $(16.5 \%)$ than random locations $(8.2 \%)$.

\section{DISCUSSION}

Pen-reared Attwater's prairie chickens selected areas where vegetation was less dense (mean obstruction of vision $=1.5$ $\mathrm{dm})$ than vegetation at random locations. Areas selected were also relatively open, containing little or no litter (mean litter depth $=2.1 \mathrm{~cm}$ ). They mostly used loamy prairie range sites interspersed with claypan prairie range sites, with the exception of soybean and fallow-field food plots. These range sites supported more grasses and forbs than sandy ranges sites. Results indicated they preferred more open habitats created by higher stocking rates.

Areas used by pen-reared Attwater's prairie chickens were similar to those used by wild Attwater's prairie chickens in studies by Horkel (1979) and Morrow (1986). They found Attwater's prairie chickens courted and fed in areas of light cover ( $<25$-cm height; $<1.5$-dm obstruction of vision). They also noted Attwater's prairie chickens roosted and fed in areas characterized by $25-\mathrm{cm}$ to $40-\mathrm{cm}$ plant height and $1-\mathrm{dm}$ to $2-\mathrm{dm}$ obstruction of vision. Nest sites were usually bunch grasses with obstruction of vision measurements averaging 2.1-2.8 dm (Cogar et al. 1977; Lutz 1979; Lawrence 1982; and Morrow 1986) interspersed in relatively open areas, allowing for high hen and brood mobility. Lehmann (1941), Cogar et al. (1977), and Morrow (1986) reported that Attwater's prairie chickens generally avoided cover in which plant heights exceeded $60 \mathrm{~cm}$ and visual obstruction exceeded $3 \mathrm{dm}$.

During spring 1997, grasses $<60-\mathrm{cm}$ tall were virtually nonexistent within the range of Attwater's prairie chickens on Attwater Prairie Chicken National Wildlife Refuge. Thus, penreared Attwater's prairie chickens on the refuge used areas where plant heights averaged $67.3 \mathrm{~cm}$, which was the shortest vegetation available. However, in 1997, 3 birds left the refuge for adjoining areas. Areas used by Attwater's prairie chickens outside of Attwater Prairie Chicken National Wildlife Refuge boundaries consisted largely of fallow rice fields and heavily grazed pastures (Lockwood 1998).

Winter through summer of 1996 were dry seasons, and the impact of cattle on Attwater Prairie Chicken National Wildlife
Refuge pastures probably provided the low obstruction of vision, plant height, and litter depth measurements; thus, pasture conditions were favorable for Attwater's prairie chickens. Conversely, spring through fall of 1997 were wet seasons and stocking rate was consistent with 1996 (USFWS, unpublished data, 1997). Cursory observations recorded throughout 19961997 indicated vegetation was less dense in 1996 (resulting from consistent stocking rates during a period of less rainfall) than in 1997. Consequently, with the more abundant rainfall in 1997 and more dense vegetation, many of the 33 pen-reared Attwater's prairie chickens released during a second release in 1997, dispersed from the refuge (Lockwood 1998).

The Attwater Prairie Chicken National Wildlife Refuge should implement a grazing strategy that will produce vegetative structure and forb production that are preferred by penreared Attwater's prairie chickens. Otherwise, the likelihood of Attwater's prairie chickens dispersing from the refuge following subsequent releases is high.

\section{LITERATURE CITED}

CogaR, V. F., J. D. Horkel, and N. J. Silvy. 1977. Vegetation type preference of Attwater's prairie chicken in coastal prairie. Proceeding of the Annual Conference of the Southeastern Association of Fish and Wildlife Agencies. 32:234-241.

GouLD, F. W. 1975. Texas plants-A checklist and ecological summary. College Station, TX: Texas Agricultural Experiment Station. Miscellaneous publication 585. $121 \mathrm{p}$.

HoRKEL, J. D. 1979. Cover and space requirements for Attwater's prairie chicken (Tympanuchus cupido attwateri) in Refugio County, Texas [dissertation]. College Station, TX: Texas A\&M University. 96 p.

LAWRENCE, J. S. 1982. Effect of predator reduction on the reproductive success of Attwater's prairie chicken [thesis]. College Station, TX: Texas A\&M University. $105 \mathrm{p}$.

Lehmann, V. W. 1941. Attwater's prairie chicken, its life history and management. Washington, DC: US Fish and Wildlife Service. North American Fauna Series $57.65 \mathrm{p}$.

Lockwood, M. A. 1998. Survival, reproduction, and habitat use of captive-reared Attwater's prairie chicken [thesis]. College Station, TX: Texas A\&M University. $68 \mathrm{p}$.

LUTZ, R. S. 1979. The response of Attwater's prairie chicken to petroleum development [thesis]. College Station, TX: Texas A\&M University. $82 \mathrm{p}$.

Morrow, M. E. 1986. Ecology of Attwater's prairie chicken in relation to land management practices on the Attwater Prairie Chicken National Wildlife Refuge [dissertation]. College Station, TX: Texas A\&M University. 100 p.

Morrow, M. E., R. S. Adamcik, J. D. Friday, and L. B. McKinney. 1996. Factors affecting Attwater's prairie-chicken decline on the Attwater Prairie Chicken National Wildlife Refuge. Wildlife Society Bulletin 24:593-601.

OTT, R. L. 1993. An introduction to statistical methods and data analysis. 4th ed.. Belmont, CA: Duxbury Press. $332 \mathrm{p}$.

Peterson, M. J. 1994. Attwater's prairie chicken limiting factors [dissertation]. College Station, TX: Texas A\&M University. $148 \mathrm{p}$.

Robel, R. J., J. N. Briggs, J. J. Cebula, N. J. Silvy, C. E. Viers, and P. G. Watt. 1970. Greater prairie chicken ranges, movements, and habitat usage in Kansas. Journal of Wildlife Management 34:286-306.

SEAL, U. S. 1994. Attwater's prairie chicken population and habitat viability assessment. Apple Valley, MN: Captive Breeding Specialist Group. International Union for the Conservation of Nature. $80 \mathrm{p}$.

[USFWS] US FISH AND WILdLIFE SERVICE. 1993. Attwater's prairie chicken recovery plan. Albuquerque, NM: USFWS. $48 \mathrm{p}$.

White, G. C., AND R. A. Garrott. 1990. Analysis of wildlife radio-tracking data. San Diego, CA: Academic Press. 383 p. 